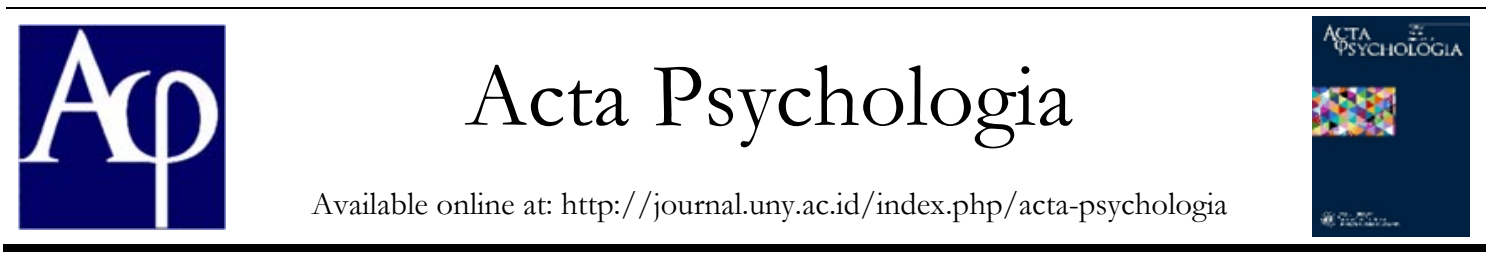

\title{
Regulasi Emosi, Lama Pasien Menjalani Terapi, dan Penerimaan Diri atas Penyakit Kronis pada Pasien Hemodialisa
}

\author{
Khairunissa Dhara Damariatna \\ Jurusan Psikologi, Universitas Negeri Yogyakarta; Jl. Colombo No. 1 Sleman Yogyakarta, 55281 \\ khairunissadharad@gmail.com
}

\begin{abstract}
Abstrak
Penelitian ini bertujuan untuk melihat hubungan antara regulasi emosi dan penerimaan diri atas penyakit kronis pada pasien hemodialisa dan melihat apakah hubungan kedua variabel tersebut dimediasi oleh lama pasien menjalani hemodialisa. Penelitian dilakukan di Rumah Sakit Happy Land Yogyakarta. Subjek penelitian berjumlah 83 pasien hemodialisa dengan menggunakan teknik pengambilan sampel purposive random sampling. Pengambilan data menggunakan skala ERQ dengan validitas 0,97 dan reliabilitas 0,9 serta CIAQ dengan validitas 0,94 dan reliabilitas sebesar 0,8. Analisis data dilakukan dengan metode uji korelasi pearson product moment dan uji variabel mediator dengan analisis regresi Hayes. Hasil penelitian menunjukkan bahwa regulasi emosi dan penerimaan diri atas penyakit kronis memiliki korelasi dengan nilai koefisien 0,23 yang berarti hubungan lemah. Setelah dihadirkan variabel mediator berupa lama pasien menjalani hemodialisa, didapat koefisien korelasi sebesar 0,81 yang berarti hubungan sangat kuat. Hasil akhir dari penelitian ini yaitu terdapat hubungan antara regulasi emosi dan penerimaan diri atas penyakit kronis yang dimediatori oleh lama pasien menjalani hemodialisa.
\end{abstract}

Kata Kunci: regulasi emosi, penerimaan diri atas penyakit kronis, lama hemodialisa, pasien hemodialisa

\begin{abstract}
Aim of the study is to asses emotion regulation, self acceptance of chronic illness, and the length of hemodialysis treatment on hemodialysis patients and to prove the correlation about those three variable, where the length of hemodialysis treatment is the mediator variable. Quantitative study with descriptive correlational research. The research was performed in Happy Land Hospital Yogyakarta with 83 hemodialysis patients as a subject. The research using emotion regulation questionnaire and chronic illness acceptance scale as the data collection tools. Analyze method of the study is Pearson product moment and Hayes method of regression. The result is emotion regulation and self acceptance of chronic illness shows that the analysis result is 0,23 of correlation coefficient - correlation are weak. After the mediator variable, length of hemodialysis treatment are combined, the correlation reach 0,81 - the correlation are strong. The final result is regulation emotion and self acceptance of chronic illnees was mediated by the length of hemodialysis treatment.
\end{abstract}

Keywords: regulation emotion, self acceptance of chronic illnes, lenght of hemodialysis treatment, hemodialysis patient

\section{Pendahuluan}

Kesehatan merupakan suatu hal yang pasti diperhatikan oleh setiap manusia. Pada kehidupan sehari-hari, seseorang bisa beraktivitas, berinteraksi, dan berkarya karena adanya kesehatan yang seimbang di dalam diri mereka. Seperti yang dikatakan oleh Straub (2014:15) bahwa kesehatan terdiri dari 2 aspek yaitu kesehatan fisik dan kesehatan psikis. Kesehatan fisik dan kesehatan psikis sangat kuat berhubungan. Hal ini yang mendasari Straub (2014:16) mengatakan bahwa setiap orang membutuhkan kesehatan yang seimbang dalam kehidupannya untuk bisa melakukan aktivitas dengan baik, sehingga 
setiap orang pasti berusaha untuk menjaga kesehatannya.

Tidak bisa dipungkiri bahwa masalah kesehatan adalah masalah yang pasti ditemui oleh setiap makhluk hidup terutama manusia. Masalah kesehatan yang paling mudah diidentifikasi adalah masalah yang berhubungan dengan kesehatan fisik, seperti flu, sakit kepala, radang tenggorokan, bahkan hingga kanker, diabetes, atapun HIV/AIDS. Penyakitpenyakit tersebut sudah menjadi masalah yang membutuhkan fokus lebih dan mulai sering diperbincangkan oleh Menteri Kesehatan Indonesia sejak tahun 2000 hingga saat ini.

Kesehatan fisik dan psikis erat berhubungan, begitu juga dengan pasien dengan penyakit kronis. Widagdo (2013: 7) mengatakan bahwa sebanyak $20-40 \%$ pasien rawat inap dan rawat jalan di rumah sakit Indonesia mengalami gangguan psikiatri. Sebagian besar pasien rawat inap dan rawat jalan tersebut adalah pasien dengan penyakit kronis. Sehingga melalui penelitiannya, disebutkan bahwa 76\% pasien dengan penyakit kronis mengalami gejala depresi karena pada setiap pasien yang menderita penyakit kronis memiliki resiko sebesar 4,6\% lebih besar untuk mengalami gangguan kesehatan mental berupa depresi.

Dewasa ini, menurut Menteri Kesehatan Indonesia Tahun 2016 (melalui Riset Dasar Kesehatan Indonesia tentang Penyakit Kronis), seiring berkembangnya gaya hidup manusia gagal ginjal kronis menjadi sebuah penyakit yang berkembang sangat cepat. Sejak tahun 1990, penyakit gagal ginjal kronis menduduki peringkat ke 27, mulai naik ke peringkat 18 di tahun 2010 dan naik lagi menjadi peringkat 5 pada tahun 2016. Mulai tahun 2016 penyakit gagal ginjal menduduki peringkat nomor 5 penyumbang kematian terbesar di Indonesia dengan jumlah kematian sebanyak 2.204 pasien per tahun.
Pasien aktif hemodialisa (HD) di tahun 2016 tercatat mencapai 78.281 jiwa dengan ratarata penambahan pasien baru dari tahun sebelumnya sebanyak 6.060 jiwa. Pada tahun 2018, tercatat pasien gagal ginjal mengalami kenaikan sebesar 3,8 persen dari jumlah sebelumnya. Hal tersebut menyebabkan permasalahan gagal ginjal menjadi suatu fokus masalah baru dan penting untuk digali lebih dalam (Salbiah, 2018).

Pasien gagal ginjal kronis menjadi penyumbang angka kematian yang besar karena pada pasien-pasien gagal ginjal kronis ini, mereka harus menjalani sebuah terapi fisik yang disebut dengan Hemodialisa atau cuci darah. Hemodialisa sudah dilakukan dipelbagai penjuru dunia untuk mengatasi permasalahan gagal ginjal kronik. Metode, jadwal terapi, dan prosedur hemodialisa berbeda-beda sesuai negara dan rumah sakit yang menangani (Chaidar, 2011:7). Aspek kesehatan mental yang dapat digali lebih dalam dan memiliki tingkat urgensi tinggi pada pasien hemodialisa adalah regulasi emosi dan penerimaan diri terhadap penyakit. Feroze (2011:4) menyatakan bahwa penerimaan diri atas penyakit kronis yang dimiliki oleh pasien adalah kunci keberhasilan pasien menjalani hidup yang berkualitas baik. Pada penelitian ini, peneliti lebih menekankan pada hubungan regulasi emosi dengan penerimaan diri atas penyakit yang diderita pada pasien hemodialisa dan bagaimana hubungan lamanya hemodialisa termasuk masa recovery atau lama pasien menjalani terapi hemodialisa memediasi hubungan di antara keduanya.

\section{Metode Penelitian}

Penelitian ini menggunakan pendekatan penelitian kuantitatif deskripsi korelasi yang dilakukan pada bulan November 2019 di Rumah Sakit Happy Land Yogyakarta. Subjek dari penelitian ini berjumlah 83 pasien hemodialisa atau cuci darah dengan rentang usia $14-75$ tahun. 
Teknik sampling yaitu purposive random sampling dengan populasi 120 pasien aktif hemodialisa di Rumah Sakit Happy Land Yogyakarta pada bulan Oktober Desember 2019 yang kemudian diambil 83 pasien sebagai sampel. Proses pengambilan data dilakukan dengan metode kuesioner berskala like likert. Instrumen yang digunakan yaitu skala Emotion Regulation Questionnaire (ERQ) dan Chronic Illness Acceptance Questionnaire (CIAQ). Sesuai dengan tujuan penelitian maka penelitian ini menggunakan teknik analisis data Pearson Product Moment sebagai uji korelasional dan teknik analisis data Regresi Hayes sebagai uji variabel mediator.

Penelitian ini menggunakan pendekatan kuantitatif deskripsi korelasi.

Penelitian dilakukan pada bulan November 2019 di Rumah Sakit Happy Land Yogyakarta.

Subjek dari penelitian ini berjumlah 83 pasien hemodialisa atau cuci darah dengan rentang usia $14-75$ tahun. Teknik sampling yaitu purposive random sampling dengan populasi 120 pasien aktif hemodialisa di Rumah Sakit Happy Land Yogyakarta pada bulan Oktober Desember 2019 yang kemudian diambil 83 pasien sebagai sampel dengan berlandaskan panduan Tabel Krejcie untuk memastikan hasil penelitian mencapai tingkat kepercayaan 95\%. Kriteria Kriteria inklusi yang ditentukan dalam penelitian ini adalah responden merupakan pasien terapi hemodialisa yang masih menjadi pasien aktif di Rumah Sakit Happy Land Yogyakarta pada bulan November sampai dengan Desember. Kriteria ekslusi pada penelitian ini yaitu pasien aktif hemodialisa yang mengalami satu atau lebih hambatan pada proses pengambilan data seperti: berusia lebih dari 75 tahun, kesulitan mendengar dan berbicara, merasakan sakit fisik yang teramat sangat bahkan lemas pada saat proses hemodialisa, pasien hemodialisa yang memiliki komplikasi dengan penyakit lain (TBC, Hepatitis, pasien ruang ICU, dan pasien ruang ICCU) sehingga dari pihak rumah sakit tidak mengizinkan dilakukan penelitian pada pasien-pasien tersebut.

Penelitian ini diawali dengan pengumpulan data menggunakan metode kuesioner berskala yaitu ERQ dan CIAQ.

Analisis data yang digunakan pada penelitian ini yaitu Pearson Product Moment dan Analisis Regresi Hayes.

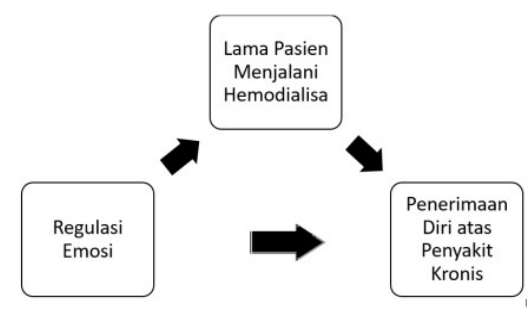

Gambar 1. Hubungan Tiga Variabel

Data, Intrumen, dan Teknik Pengumpulan Data

Teknik pengumpulan data Azwar (2005) menjelaskan bahwa teknik pengumpulan data dalam kegiatan penelitian mempunyai tujuan mengungkap fakta mengenai variabel yang diteliti. Teknik pengumpulan data yang digunakan dalam penelitian ini yaitu metode kuesioner atau angket berskala.

Skala yang digunakan yaitu skala intensitas dengan tujuh pilihan jawaban karena bisa mengungkapkan keadaan subjek dengan lebih akurat sesuai dengan keadaan diri subjek. Rentang skala dalam penelitian ini dimulai dari tidak pernah (TP), sangat jarang (SJ), jarang, kadang-kadang (K), hampir sering (HS), sering (SE), sangat sering (SS), selalu (S). Skala ini memiliki alternatif jawban yaitu tidak pernah bernilai 1, sangat jarang bernilai 2, jarang bernilai 3, kadang-kadang bernilai 4, hampir sering bernilai 5 , sering bernilai 6 , sangat sering bernilai 7 , dan selalu bernilai 8 .

Instrumen pengumpulan data Instrumen penelitian adalah suatu alat yang digunakan untuk mengukur fenomena alam maupun sosial yang diamati. Fenomena tersebut dikenal sebagai variabel penelitian 
(Creswell, 2014). Penelitian ini menggunakan instrumen skala intensitas yaitu skala penerimaan diri atas penyakit kronis dan skala regulasi emosi.

Skala penerimaan diri atas penyakit kronis disusun oleh Beacham, A.O \& Kinman, C.R. Skala ini digunakan untuk mengukur seberapa tinggi penerimaan diri subjek atas penyakit kronis yang dimilikinya. Semakin tinggi skor yang diperoleh subjek maka semakin tinggi pula penerimaan diri atas penyakit kronisnya. Hal tersebut dapat diketahui berdasarkan alternatif jawabannya berupa angka yang tertera pada skala. Penelitian yang dilakukan oleh Isroin (2017: 175181) menggunakan skala penerimaan diri atas penyakit kronis untuk mengukur penerimaan diri pasien hemodialisa. Kisi-kisi yang digunakan dalam skala penerimaan diri atas penyakit kronis yaitu:

Skala regulasi emosi disusun oleh Gross, J.J., \& John, O.P. Skala ini digunakan untuk mengukur seberapa baik regulasi emosi yang dimiliki oleh subjek. Semakin tinggi skor yang diperoleh maka semakin baik pula kemampuan regulasi emosi subjek. Pada penelitian Armiyati (2014: 18) skala regulasi emosi digunakan untuk mengukur aspek regulasi emosi pada pasien hemodialisa.

Azwar (2007: 42-44) menjelaskan tentang uji validitas yang digunakan untuk mengukur validitas instrumen adalah validitas isi. Validitas isi adalah validitas yang diestimasi lewat pengujian terhadap isi tes dengan analisis rasional atau melewati expert judgement. Dalam pengujian validitas, expert judgement menelaah tiap butir pernyataan untuk mengetahui sejauhmana kelayakan suatu instrumen alat ukur sebagai sampel dari dominana butir pernyataan yang hendak diukur. Kelayakan diukur dengan nilai yang diberikan oleh expert judgement pada tiap butir sebagai penjelasan dari indikator dan aaspek yang akan diukur. Validitas dapat dikatakan baik apabila memiliki nilai $>0,6$.
Validitas instrumen dianalisis dengan metode analisis Gregory:

Tabel 1. Tabel Validitas Penerimaan Diri dan Regulasi Emosi atas Penyakit Kronis

\begin{tabular}{|c|c|c|}
\hline \multirow{2}{*}{$\begin{array}{l}\text { Validitas } \\
\text { Gregory }\end{array}$} & \multicolumn{2}{|c|}{ Koefisien } \\
\hline & $\begin{array}{c}\text { Penerimaan } \\
\text { diri }\end{array}$ & $\begin{array}{c}\text { Regulasi } \\
\text { Emosi } \\
\end{array}$ \\
\hline V12 & 0,9 & 0,96 \\
\hline V13 & 1 & 1 \\
\hline V23 & 0,93 & 0,96 \\
\hline Rata-rata & 0,94 & 0,97 \\
\hline
\end{tabular}

Dari tabel 1 diperoleh nilai validitas dari instrumen penerimaan diri atas penyakit kronis sebesar $0,94 \quad(>0,06)$ sehingga validitas baik.

Dari tabel 1 juga diperoleh nilai validitas dari instrumen regulasi emosi sebesar 0,97 (>0,06) sehingga validitas baik.

Jika item yang disusun tidak sesuai untuk mengukur maka akan direvisi. Hanya item yang memiliki kualitas baik akan digunakan dalam tes. Azwar (2015: $152-$ 153) menjelaskan kualitas item yang baik adalah keselarasan atau konsistensi antara item dengan tes secara keseluruhan, yang biasa disebut dengan konsistensi item-total.

Azwar (2015: 139) mengatakan bahwa batas minimal koefisien korelasi item total sebesar 0,3 namun apabila jumlah item yang lolos masih belum mencukupi maka dapat dilakukan pertimbangan utnuk menurunkan sedikit batas kriteria menjadi 0,2 sehingga jumlah item yang diinginkan dapat tercapai. Hasil uji keseluruhan item pada skala regulasi emosi dengan jumlah 10 item yang diujikan kepada 83 responden dinyatakan seluruh item valid karena item memiliki koefisien item total di atas 0,25 atau $>0,25$, begitu juga dengan skala penerimaan diri atas penyakit kronis dinyatakan valid karena item memiliki koefisien item total di atas 0,25 atau >0,25. 
Tabel 2. Seleksi Butir Soal

\begin{tabular}{|c|c|c|c|c|}
\hline \multirow[b]{2}{*}{ Skala } & \multicolumn{3}{|c|}{ Butir } & \multirow[b]{2}{*}{$\begin{array}{l}\text { Keter } \\
\text { angan }\end{array}$} \\
\hline & Gugur & $\begin{array}{l}\text { Tidak } \\
\text { gugur }\end{array}$ & $\begin{array}{l}\text { Soal } \\
\text { akhir }\end{array}$ & \\
\hline $\begin{array}{l}\text { Regulasi } \\
\text { emosi }\end{array}$ & 0 & 10 & 10 & $\begin{array}{l}\text { Favor } \\
\text { able }\end{array}$ \\
\hline $\begin{array}{l}\text { Penerima } \\
\text { an diri } \\
\text { atas } \\
\text { penyakit } \\
\text { kronis }\end{array}$ & 6 & 17 & 17 & $\begin{array}{l}\text { Favor } \\
\text { able }\end{array}$ \\
\hline
\end{tabular}

Pada tabel 2 dijelaskan bahwa pada skala regulasi emosi, semua butir soal memiliki koefisien korelasi di atas 0,25 sehingga semua butir soal baik dan tidak ada yang digugurkan. Pada skala penerimaan diri atas penyakit kronis, terdapat 6 butir soal yang memiliki koefisien korelasi di bawah 0,25, sehingga dari total 23 butir soal jumlah keseluruhan menjadi 17 butir soal.

Pada berbagai bentuk skala psikologi yang mengukur satu atribut komposit, skor subjek pada skala tidak berasal hanya dari satu sumber saja melainkan ditentukan oleh gabungan dari beberapa skor. Beberapa skor tersebut bisa dari bagian skala itu sendiri, dapat pula berasal dari skala lain yang berbeda. Skor akhir pada skala merupakan skor komposit (Azwar, 2017: 123). Reliabilitas komposit dapat dikatakan baik apabila memiliki nilai di atas 0,6.

Berdasarkan tabel 3, diperoleh perhitungan reliabilitas komposit skala regulasi emosi sebesar 0,9 , sehingga reliabilitas komposit skala regulasi emosi baik.
Tabel 3. Penghitungan Reliabilitas Skala Regulasi Emosi

\begin{tabular}{lll}
\hline \multicolumn{1}{c}{ Komponen } & $\begin{array}{c}\text { Regulasi } \\
\text { Emosi }\end{array}$ & $\begin{array}{c}\text { Penerima } \\
\text { an Diri }\end{array}$ \\
\hline Reliabilitas dimensi 1 & 0,71 & 0.6 \\
Reliabilitas dimensi 2 & 0,81 & 0.4 \\
Reliabilitas dimensi 3 & 0,5 & 0.7 \\
Var dimensi 1 & 36 & 9.6 \\
Var dimensi 2 & 128 & 11.2 \\
Var dimensi 3 & 6,7 & 22.9 \\
Var Total & 252,2 & 65.442 \\
Reliabilitas Komposit & 0,9 & 0.8 \\
\hline
\end{tabular}

Berdasarkan tabel 3 juga diperoleh perhitungan reliabilitas komposit skala penerimaan diri sebesar 0,8, sehingga reliabilitas komposit skala penerimaan diri atas penyakit kronis baik.

Pada uji reliabilitas dan uji validitas instrumen dilakukan pengujian dengan metode try out terpakai. Penggunaan metode try out terpakai dalam uji coba alat ukur bisa dilakukan dengan tujuan untuk mendapatkan hasil yang bisa digeneralisir. Metode ini juga bisa digunakan apabila subjek penelitian memiliki kriteria khusus dan tidak bisa diteliti pada sembarang subjek (Widiharso, 2013: 24).

Teknik analisis data pada penelitian ini menggunakan uji prasyarat yaitu uji linearitas dan uji normalitas setelah itu dilakukan uji hipotesis.

Variabel bebas pada penelitian ini adalah regulasi emosi, variabel terikat adalah penerimaan diri atas penyakit kronis, sedangkan variabel mediator adalah lamanya pasien menjalani terapi hemodialisa. Sebelum melakukan analisis data untuk menguji hipotesis, diperlukan uji 
prasyarat analisis yang meliputi uji normalitas dan uji hipotesis.

Uji normalitas dilakukan dengan tujuan mengetahui data yang bersangkutan memenuhi ciri sebaran normal atau tidak. Dalam penelitian ini, uji normalitas dilakukan dengan menggunakan perhitungan model KolomogorovSmirnov dengan bantuan SPSS for Windows.

Analisis uji hipotesis pada penelitian ini yaitu dengan metode analisis uji hubungan atau korelasi. Metode ini digunakan untuk menguji hubungan atau keterikatan antara variabel. Dalam uji korelasi, yang dianalisis adalah seberapa besar kekuatan hubungan antar variabel tersebut (Farida, 2016:82).

Analisis data akan dilakukan dengan analisis korelasi Pearson dan analisis regresi Hayes karena analisis ini termasuk metode analisis data parametrik dimana kedua variabel yang dianalisis berbentuk interval atau skala likert (Farida, 2016: 87). Analisis regresi Hayes digunakan untuk melihat apakah variabel mediator benar-benar memediasi dua variabel.

\section{Hasil Penelitian dan Pembahasan}

Hasil dari penelitian ini terdiri dari data statistic masing-masing variabel, hubungan antara tiga variabel, dan analisis variabel mediator.

Deskripsi Data Statistik Hasil Penelitian Regulasi Emosi

Skala regulasi emosi dengan rentang skor $1-8$ dengan jumlah 10 item pernyataan. Deskripsi data disajikan secara umum dari regulasi emosi yang terdiri dari: skor minimun, skor maksimum, mean, dan standar deviasi.
Tabel 4. Data Statistik Variabel Regulasi Emosi:

\begin{tabular}{l|lll}
\multicolumn{1}{c}{ Statistik Deskriptif } & \multicolumn{1}{c}{ Ideal } & \multicolumn{2}{c}{ Hipotetik } \\
\hline Mean & 45 & $10+(\max -\min ) / 2$ & 45 \\
Standar Deviasi & 11,7 & $($ max-min $) / 6$ & 11,7 \\
Skor Maksimal & 80 & Skor max responden & 71 \\
Skor Minimal & 10 & Skor min responden & 25
\end{tabular}

Tabel 5. Data Strategi Regulasi Emosi

\begin{tabular}{|l|c|c|}
\hline Strategi Regulasi Emosi & Jumlah Pasien & Presentase \\
\hline Pengalihan perhatian & 30 & $36 \%$ \\
\hline Perubahan kognitif & 22 & $27 \%$ \\
\hline Penyesuaian respon & 31 & $37 \%$ \\
\hline & TOTAL & $100 \%$ \\
\hline
\end{tabular}

Tabel 6. Perhitungan Kategorisasi Regulasi Emosi:

\begin{tabular}{|l|l|r|r|r|}
\hline \multicolumn{2}{|c|}{ Kategori } & Frequency & Percent & Valid Percent \\
\hline \multirow{8}{*}{} & Sangat Rendah & 12 & 14.5 & 14.5 \\
\cline { 2 - 5 } & Rendah & 15 & 18.1 & 18.1 \\
\cline { 2 - 5 } & Sedang & 36 & 43.4 & 43.4 \\
\cline { 2 - 5 } & Tinggi & 13 & 15.7 & 15.7 \\
\cline { 2 - 5 } & Sangat Tinggi & 7 & 8.4 & 8.4 \\
\cline { 2 - 5 } & Total & 83 & 100.0 & 100.0 \\
\hline
\end{tabular}

Berdasarkan tabel di atas, tingkat regulasi emosi pada pasien hemodialisa di Rumah Sakit Happy Land terbagi menjadi lima kategori yaitu sangat rendah, rendah, sedang, tinggi, dan sangat tinggi. Sebanyak 12 pasien $(14,5 \%)$ memiliki tingkat regulasi emosi yang sangat rendah, 15 pasien $(18,1 \%)$ memiliki regulasi emosi rendah, 36 pasien $(43,4 \%)$ pasien memiliki tingkat regulasi emosi sedang, 13 pasien $(15,7 \%)$ memiliki regulasi emosi tinggi, dan sebanyak 7 pasien $(8,4 \%)$ memiliki regulasi emosi yang sangat tinggi. Dengan demikian, dapat disimpulkan bahwa rata-rata pasien hemodialisa di Rumah Sakit Happy Land memiliki tingkat regulasi emosi sedang cenderung rendah. 
Penerimaan Diri Atas Penyakit Kronis

Skala penerimaan diri atas penyakit kronis dengan rentang skor $1-8$ dengan jumlah 17 item pernyataan. Deskripsi data disajikan secara umum dari penerimaan diri atas penyakit kronis yang terdiri dari: skor minimun, skor maksimum, mean, dan standar deviasi.

Tabel 7. Data Statistik Variabel Penerimaan Diri atas Penyakit Kronis

\begin{tabular}{l|lll}
\multicolumn{1}{c|}{ Statistik Deskriptif } & Ideal & \multicolumn{2}{c}{ Hipotetik } \\
\hline Mean & 88 & $10+(\max -m i n) / 2$ & 76,5 \\
Standar Deviasi & 31 & $($ max-min $) / 6$ & 19,8 \\
Skor Maksimal & 136 & Skor max responden & 128 \\
Skor Minimal & 17 & Skor min responden & 17
\end{tabular}

Tabel 8. Perhitungan Kategorisasi Penerimaan Diri atas Penyakit Kronis

\begin{tabular}{|l|l|r|r|r|}
\hline \multicolumn{2}{|c|}{} & Frequency & Percent & $\begin{array}{c}\text { Valid } \\
\text { Percent }\end{array}$ \\
\hline \multirow{3}{*}{ Valid } & Sangat Rendah & 23 & 27.7 & 27. \\
\cline { 2 - 5 } & Rendah & 27 & 32.5 & 32. \\
\cline { 2 - 5 } & Sedang & 12 & 14.5 & 14. \\
\cline { 2 - 5 } & Tinggi & 12 & 14.5 & 14. \\
\cline { 2 - 5 } & Sangat Tinggi & 9 & 10.8 & 10. \\
\cline { 2 - 5 } & Total & 83 & 100.0 & 100. \\
\hline
\end{tabular}

Berdasarkan tabel di atas, tingkat penerimaan diri atas penyakit kronis pada pasien hemodialisa di Rumah Sakit Happy Land terbagi menjadi lima kategori yaitu sangat rendah, rendah, sedang, tinggi, dan sangat tinggi. Sebanyak 23 pasien $(27,7 \%)$ memiliki tingkat penerimaan diri atas penyakit kronis yang sangat rendah, sebanyak 27 pasien $(32,5 \%)$ pasien memiliki tingkat penerimaan diri atas penyakit kronis rendah, sebanyak 12 pasien $(14,5)$ memiliki tingkat penerimaan diri atas penyakit kronis sedang, sebanyak 12 pasien $(14,5)$ memiliki penerimaan diri atas penyakit kronis tinggi, dan sebanyak 9 pasien $(10,8 \%)$ memiliki penerimaan diri yang sangat tinggi. Dengan demikian, dapat disimpulkan bahwa ratarata pasien hemodialisa di Rumah Sakit Happy Land memiliki tingkat penerimaan diri atas penyakit kronis kategori sedang cenderung rendah.

Lama Pasien Menjalani Hemodialisa

Lamanya pasien menjalani hemodialisa diketahui dari berapa lama pasien sudah menjalani terapi hemodialisa. Lama pasien menjalani hemodialisa dihitung dengan satuan bulan. Deskripsi data pasien disajikan secara umum dari regulasi emosi yang terdiri dari: skor minimun, skor maksimum, mean, dan standar deviasi.

Tabel 8. Data Statistik Variabel Lama

Pasien Menjalani Hemodialisa

\begin{tabular}{l|ll}
\multicolumn{1}{c}{ Statistik Deskriptif } & \multicolumn{1}{c}{ Penghitungan } \\
\hline Mean & $10+(\max -\mathrm{min}) / 2$ & 72,5 \\
Standar Deviasi & $(\max -\mathrm{min}) / 6$ & 23,8 \\
Skor Maksimal & Skor max responden & 144 \\
Skor Minimal & Skor min responden & 1
\end{tabular}

Tabel 9. Perhitungan Variabel Lama Pasien Menjalani Hemodialisa:

\begin{tabular}{|c|c|c|c|c|}
\hline & & Frequency & Percent & Valid Percent \\
\hline \multirow[t]{6}{*}{ Valid } & $0-12$ & 59 & 71.1 & 71.1 \\
\hline & $13-24$ & 9 & 10.8 & 10.8 \\
\hline & $24-48$ & 7 & 8.4 & 8.4 \\
\hline & $48-60$ & 5 & 6.0 & 6.0 \\
\hline & $>60$ & 3 & 3.6 & 3.6 \\
\hline & Total & 83 & 100.0 & 100.0 \\
\hline
\end{tabular}

Berdasarkan tabel di atas, lama pasien menjalani hemodialisa di Rumah Sakit Happy Land sebanyak 39 pasien (71,1\%) adalah pasien yang menjalani hemodialisa selama $0-12$ bulan, 9 pasien (10,8\%) adalah pasien yang menjalani hemodialisa selama 13-24 bulan, 7 pasien $(8,4 \%)$ adalah pasien yang menjalani hemodialisa selama 24-48 bulan, 5 pasien $(6 \%)$ adalah pasien yang menjalani hemodialisa 48-60 bulan, dan 3 
pasien $(3,6 \%)$ adalah pasien yang sudah menjalani hemodialisa lebih dari 60 bulan.

Hasil Analisis Data Uji Prasyarat Analisis

Variabel bebas pada penelitian ini adalah regulasi emosi, variabel terikat adalah penerimaan diri atas penyakit kronis, sedangkan variabel mediator adalah lamanya pasien menjalani terapi hemodialisa. Sebelum melakukan analisis data untuk menguji hipotesis, diperlukan uji prasyarat analisis yang meliputi:

\section{Uji Normalitas}

Uji normalitas dilakukan dengan tujuan mengetahui data yang bersangkutan memenuhi ciri sebaran normal atau tidak. Dalam penelitian ini, uji normalitas dilakukan dengan menggunakan perhitungan model Kolomogorov Smimov dengan bantuan SPSS for Windows.

Hasil dari uji normalitas untuk variabel regulasi emosi, lamanya hemodialisa, dan penerimaan diri atas penyakit kronis berdasarkan perhitungan SPSS for Windows yaitu diperoleh nilai signifikansi dari analisis Kolomogorov-Smimov test sebesar 0,2 (sig > 0,05) yang berarti data berdistirbusi normal.

Uji Linearitas

Uji linearitas adalah uji yang digunakan untuk mengetahui apakah hubungan variabel bebas dan variabel terikat berada pada satu garis linear atau tidak. Uji linearitas pada penelitian menggunakan SPSS for Windows, jika kedua variabel memiliki nilai $\alpha>0,05$ maka dapat dikatakan linear, sedangkan jika kedua variabel memiliki nilai $\alpha<0,05$ maka hubungan dua variabel dikatakan tidak linear.

Hasil penghitungan uji linearitas berdasarkan nilai signifikansi dari tabel di atas, dihasilkan nilai $\alpha$ untuk variabel regulasi emosi dan penerimaan diri atas penyakit kronis sebesar 0,272 ( $\mathrm{p}>0,05)$ dengan F hitung 1.209. Kemudian berdasarkan nilai signifikansi, dihasilkan nilai $\alpha$ untuk variabel lama menjalani terapi dan penerimaan diri atas penyakit kronis sebesar 0,199 ( $\mathrm{p}>0,05)$ dengan $\mathrm{F}$ hitung 1.310. Oleh karena itu, variabel penelitian dapat dikatakan memiliki hubungan yang linear, maka dapat dilakukan uji koefesien korelasi dengan menggunakan metode Pearson Product Moment untuk mengetahui hubungan antara regulasi emosi dengan penerimaan diri atas penyakit kronis, hubungan antara regulasi emosi dengan lama menjalani hemodialisa, dan hubungan antara lama menjalani hemodialisa dengan penerimaan diri atas penyakit kronis.

\section{Uji Hipotesis}

Hipotesis merupakan jawaban sementara atas rumusan masalah. Pengujian hipotesis menggunakan teknik korelasi Pearson Product Moment dengan bantuan SPSS for Windows. Ketentuan kuat lemahnya suatu hubungan menurut Pearson adalah 0,8 - 1 sangat kuat, $0,6-0,79$ kuat, 0,4

Uji hipotesis pertama, berdasarkan analisis menggunakan SPSS diperoleh penghitungan pada variabel regulasi emosi dan penerimaan diri atas penyakit kronis yaitu $r=0,815(\alpha=0,000(p<0,01))$ yang berarti $\mathrm{Ha}$ diterima dan $\mathrm{HO}$ ditolak, sehingga terdapat hubungan yang signifikan antara regulasi emosi dan penerimaan diri atas penyakit kronis. Selanjutnya penghitungan pada variabel regulasi emosi dengan lama pasien menjalani hemodialisa yaitu $r=0,484(\alpha=0,000(p<0,01))$ yang berarti $\mathrm{Ha}$ diterima dan $\mathrm{HO}$ ditolak, sehingga terdapat hubungan yang signifikan antara regulasi emosi dengan lama pasien menjalani hemodialisa. Penghitungan pada variabel penerimaan diri atas penyakit kronis dengan lama pasien menjalani hemodialisa diperoleh $\mathrm{r}=0,575(\alpha=0,000$ $(\mathrm{p}<0,01))$ yang berarti Ha diterima dan $\mathrm{H} 0$ ditolak, sehingga terdapat hubungan yang signifikan antara penerimaan diri atas penyakit kronis dengan lama pasien menjalani hemodialisa.

Menurut analisis regresi Hayes, hubungan antara regulasi emosi dan lama 
pasien menjalani hemodialisa

memiliki koefisien sebesar 0,48 dan $p$ sebesar $0,000 \quad(p<0,01)$. Pada metode regresi Hayes untuk membuktikan variabel mediator, analisis hubungan antara regulasi emosi dan lama pasien menjalani hemodialisa akan menjadi analisis jalur a.

Hubungan antara regulasi emosi dengan penerimaan diri atas penyakit kronis memiliki koefisien sebesar 0,25 dan $\mathrm{p}=$ $0,000$ ( $p<0,01)$. Pada metode regresi Hayes untuk membuktikan variabel mediator, hasil dari analisis hubungan antara regulasi emosi dan lama pasien menjalani hemodialisa akan menjadi analisis jalur c'. Selanjutnya hubungan antara lama hemodialisa dengan penerimaan diri atas penyakit kronis memiliki koefisien sebesar 0,23 dan $\mathrm{p}=$ $0,001(\mathrm{p}<0,01)$ dan menjadi analisis jalur $\mathrm{b}$. Total effect adalah analisis untuk jalur $\mathrm{c}$ dimana terdapat koefisien yang didapat dari effect sebesar 0,8 dan $\mathrm{p}=0,000(\mathrm{p}<0,05)$. Koefisien indirect effect memiliki nilai 0,25 yang didapat melalui effect. Analisis data di atas sekaligus dapat menjelaskan efek mediasi pada ketiga variabel. Pada jalur c, terdapat koefisien sebesar 0,82 dan signifikansi 0,000 . Koefisien jalur c dilihat dari total effect pada analisis regresi Hayes yang artinya hubungan keseluruhan dari variabel bebas, variabel mediator, dan variable terikat.

Pada gambar 5 dapat dilihat c' memiliki koefisien sebesar 0,25 yang artinya hubungan antara regulasi emosi dan penerimaan diri atas penyakit kronis jika tidak digabungkan dengan lama pasien menjalani hemodialisa memiliki hubungan yang kurang kuat. Dapat disimpulkan dari dua bagan di atas bahwa lama pasien hemodialisa menjadi mediator hubungan antara regulasi emosi dan penerimaan diri atas penyakit kronis $\left(c^{\prime}<c\right)$.
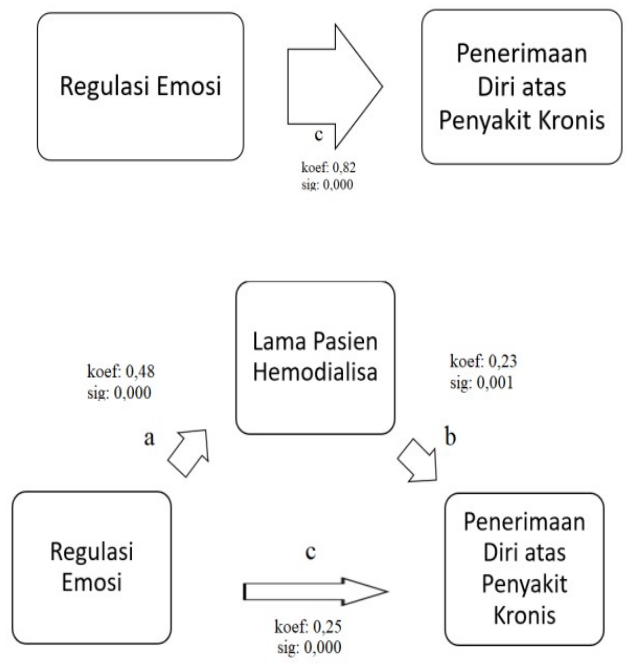

Gambar 2. Bagan Analisis Variabel

\section{Simpulan dan Saran}

Berdasarkan hasil penelitian yang telah dilakukan dan telah dibaha, maka dapat ditarik beberapa kesimpulan diantaranya yaitu (1) variabel regulasi emosi terbukti memiliki hubungan dengan penerimaan diri atas penyakit kronis. Hal tersebut dibuktikan dengan hasil analisis regresi Hayes yaitu nilai $r=0,25(\alpha=0,000)$. Berdasarkan hasil analisis, nilai signifikansi sebesar 0,000 dimana $\mathrm{p}<0,01$ sehingga kedua variabel berhubungan dan hipotesis pertama diterima, (2) variabel regulasi emosi terbukti memiliki hubungan dengan lama pasien menjalani hemodialisa. Hal tersebut dibuktikan dengan hasil analisis regresi Hayes yaitu nilai $\mathrm{r}=0,484(\alpha=0,000(\mathrm{p}<$ $0,01)$ ) yang berarti terdapat hubungan antara regulasi emosi dengan lama pasien menjalani hemodialisa, (3) variabel penerimaan diri atas penyakit kronis terbukti berhubungan dengan lama pasien menjalani hemodialisa. Hal tersebut dibuktikan dengan hasil analisis regresi Hayes yaitu nilai $\mathrm{r}=0,23(\alpha=0,000(\mathrm{p}<$ $0,01)$ ), yang berarti terdapat hubungan antara penerimaan diri atas penyakit kronis dengan lamanya pasien menjalani hemodialisa, (4) Variabel lama pasien 
menjalani hemodialisa terbukti menjadi mediator hubungan antara regulasi emosi dan penerimaan diri atas penyakit kronis. Hal tersebut dibuktikan dengan analisis regresi Hayes yang digunakan untuk membuktikan adanya variabel mediator. Hasil analisis menunjukkan bahwa koefisien korelasi antara regulasi emosi dengan penerimaan diri atas penyakit kronis sebelum dimediasi sebesar 0,25 kemudian meningkat menjadi 0,82 setelah dimediatori oleh lama pasien menjalani hemodialisa. Berdasarkan analisis regresi Hayes tersebut, maka hipotesis kedua pada penelitian ini dinyatakan diterima.

Berdasarkan analisis di atas seluruh hipotesis pada penelitian ini dinyatakan diterima.

Berdasarkan kesimpulan yang telah disebutkan, peneliti akan memberikan saran kepada beberapa pihak yaitu tenaga kesehatan, pasien, keluarga dan masyarakat, serta peneliti selanjutnya.

Pada penelitian ini ditemukan fakta bahwa terdapat hubungan positif antara regulasi emosi, penerimaan diri atas penyakit kronis, dan lama pasien dalam menjalani terapi hemodialisa. Oleh karena itu, diharapkan tenaga kesehatan kedepannya lebih memperhatikan kondisi psikologis seperti regulasi emosi dan penerimaan diri atas penyakit kronis terutama pada pasienpasien yang baru saja menjalani terapi hemodialisa. Peningkatan layanan psikologis atau pendampingan psikologis bisa menjadi cara untuk menangani kondisi-kondisi psikis pasien hemodialisa.

Penelitian ini menemukan bahwa regulasi emosi dan penerimaan diri atas penyakit kronis pada pasien hemodialisa mayoritas sedang. Oleh karena itu, pasien diharapkan bisa meningkatkan kemampuan pengelolaan emosi dan penerimaan diri atas penyakit kronis supaya proses hemodialisa bisa berjalan seterusnya dan mampu bertahan dengan usia yang panjang.

Keluarga dan Masyarakat sekitar diharapkan bisa mendukung pasien hemodialisa sehingga pasien merasa lebih tenang dan lebih menerima kondisi diri. Keluhan apapun dari pasien cukup didengar dan pasien selalu diberi motivasi untuk tetap bertahan. Sebagai masyarakat yang memiliki kolega, tetangga, atau bertemu dengan pasien hemodialisa, diharapkan dapat membantu mereka untuk menerima kondisi diri.

Penliti selanjutnya diharapkan dapat mengembangkan penelitian ini dengan meneliti faktor atau aspek lain yang mungkin berhubungan dan memberikan kontribusi lebih besar terhadap penerimaan diri atas penyakit kronis, misalnya: tingkat pendidikan terakhir, tingkat ekonomi, dukungan sosial, keterampilan sosial, tingkat spiritual, dan budaya yang dianut oleh pasien. Selain itu, peneliti selanjutnya diharapkan dapat meneliti dengan subjek yang lebih banyak, rumah sakit yang lebih general, dan sasaran subjek lebih kepada pasien di seluruh wilayah Indonesia agar penelitian memiliki validitas dan reliabilitas yang lebih tinggi serta dapat digeneralisasikan secara umum.

\section{Daftar Pustaka}

Armiyati, (2014). Konsep Diri dan Keperawatan Diri Pasien Gagal Ginjal Kronis: Hemodalisa. Fakultas Kedokteran-Ilmu Keperawatan Universitas Indonesia Vol.16 no.2

Azwar, Saifuddin. $\quad$ (2012). Dasar-Dasar Psikometrika Edisi II. Yogyakarta: Pustaka Pelajar

Azwar, Saifuddin. (2017). Penyusunan Skala Psikologi Edisi 2. Yogyakarta: Pustaka Pelajar

Badan Pusat Statistik diakses dari http:www.bps.go.id/, diakses pada tanggal 20 Mei 2019

Barberis, N., Cernaro, V., Costa, S., Montalto, G., Lucisano, S., Larcan, R., \& Buemi, M. (2017). The relationship between coping, 
emotion regulation, and quality of life of patients on dialysis. International Journal of Psychiatry in Medicine, 52(2), 111123.

https://doi.org/10.1177/009121741 7720893

Barcik, N. Emotion control and its impact on the disease acceptance in hemodialysis patients. (2015). Journal of Public Health, Nursing, and Medical Rescue No.7/2015 (44-64barcik)

Barcik, N., \& Babiarczyk, B. (2017). Emotion control and its impact on the disease acceptance in hemodialysis patients. Journal of Public Health, Nursing and Medical Rescue, 3(3), 23-29.

Bayoumi, Magda. (2011). Identification of The Needs Of Hemodialysis Patients Using

The Concept Of Maslow's Hierarchy of Needs. College of Health Science, King Khalid University in the Medicall \& Surgical Departements

Beacham, A. O., Linfield, K., Kinman, C. R., \& Payne-Murphy, J. (2015). The chronic illness acceptance questionnaire: Confirmatory factor analysis and prediction of perceived disability in an online chronic illness support group sample. Journal of Contextual Behavioral Science, 4(2), 96102.

https://doi.org/10.1016/j.jcbs.2015.03.00

1 Bishop, D.V.M. (2016). The interface between genetics and psychology: lessons from health and clinical psychology

. Department of Experimental Psychology, University of Oxford. B 282

Chaidar, W. (2011). Hemodialisa dan Prosedurnya. Retrieved from Digilib Unnes: lib.unnes.ac.id

Chen, H. J., Wang, Y. F., Qi, R., Schoepf, U. J., Varga-Szemes, A., Ball, B. D.,
Zhang, L. J. (2017). Altered Amygdala Resting-State Functional Connectivity in Maintenance Hemodialysis End-Stage Renal Disease Patients with Depressive Mood. Molecular Neurobiology, 54(3), 22232233.

https://doi.org/10.1007/s12035$\underline{016-9811-8}$

Christensen, A. J., Benotsch, E. G., Wiebe, J. S., \& Lawton, W. J. (1995). Coping With Treatment-Related Stress: Effects on Patient Adherence in Hemodialysis. Journal of Consulting and Clinical Psychology, 63(3), 454-459. https://doi.org/10.1037/0022 $\underline{006 X .63 .3 .454}$

Creswell, J.W., (2014). Research Design : Qualitative, Quantitative and Mixed Methods Approaches : fourth edition. Sage publications, Inc.

Creswell, Jhon W. (2016). Research Design Pendekatan Kualitatif, Kuantitatif, trimdan Mixed. Yogyakarta: Pustaka Pelajar.

Departemen Kesehatan Indonesia. (2013). Prevalensi Kesehatan Indonesia: Kementrian Kesehatan RI

Departemen Kesehatan Indonesia. (2018). Prevalensi Kesehatan Indonesia: Kementrian Kesehatan RI

Dziubek, W., Kowalska, J., Kusztal, M., Rogowski, Ł., Gołębiowski, T., Nikifur, M., ... Woźniewski, M. (2016). The Level of Anxiety and Depression in Dialysis Patients Undertaking Regular Physical Exercise Training - A Preliminary Study. Kidney and Blood Pressure Research, 41(1), 86-98.

https://doi.org/10.1159/000368548

Ekman, P. (2003). Emotions revealed:

Recognizing faces and feelings to improve communication and emotional life. New York, NY: Times Books. 
Falvo, D. (n.d.). Medical and Psychosocial Aspects of Disability, Psychosocial Aspects. Rehabilitation Psychology.

Feroze, U., Martin, D., Reina-Patton, A., Kalantar-Zadeh, K., \& Kopple, J. D. (2010). Mental health, depression, and anxiety in patients on maintenance dialysis. Iranian Journal of Kidney Diseases, 4(3), 173-180.

Fitri, H., Hendriani, S., Zuhirah, H., \& Saldi, F. (2011), Adaptasi dan Rawat Diri Pasien Kronis Hemodialisa. Universitas Diponegoro. 1-10.

Ghazali, Imam. 2016. Desain Penelitian

Kuantitatif dan Kualitatif untuk. Ilmu

Sosial. Semarang: Yoga Pratama

Gillanders, S., Wild, M., Deighan, C., \& Gillanders, D. (2008). Emotion Regulation, Affect, Psychosocial Functioning, and Well-being in Hemodialysis Patients. American Journal of Kidney Diseases, 51(4), 651662.

https://doi.org/10.1053/j.ajkd.2007. $\underline{12.023}$

Gillespie, S. M., \& Beech, A. R. (2016). Theories of Emotion Regulation. The Wiley Handbook on the Theories, Assessment and Treatment of Sexual Offending, $I, \quad$ 245-263. https://doi.org/10.1002/978111857 4003.w attso012

Gregg, Jennifer \& Hoffman, dkk. 2013. The Strength of Self-Acceptance. New York: McGraw Hill

Gross, J. J. (2006). Handbook of emotion regulation (1st ed.). New York, NY, US: Guilford Press.

Gross, J., John, O. P., \& Eng, J. (1998). Three approaches to individual differences in affect regulation: Conceptualizations, measures, and findings. Handbook of emotion regulation (1 1 st ed.).
Gross, J., John, O. P., \& Eng, J. (2014). Three approaches to individual differences in affect regulation: Conceptualizations, measures, and findings. Handbook of emotion regulation ( 2 nd ed.).

Gross, James J.; John, O. P. (2013). Emotion Regulation Questionnaire (ERQ). Joumal of Personality and Social Psychology, 85, 348-362. https://doi.org/10.1037/0022 $\underline{3514.85 .2 .348}$

Harianja,N. (2010). Hubungan Kesehatan, Tubuh, dan Otak. Universitas Negeri Medan.

Hayes, S. C., \& Wilson, K. G. (1994). Acceptance and Commitment Therapy: Altering the Verbal Support for Experiential Avoidance. The Behavior Analyst, 17(2), 289-303. https://doi.org/10.1007/bf0339267 I

Hendrayani, C. I., Wirya, I. N., \& Asril, N. M. (2015). Penerapan Metode Sharing Patient pada pasien penyakit kronis dan lupus e-Journal PG PAUD Universitas Pendidikan Ganesha, 1-10.

Hofmann, S. G., Carpenter, J. K., \& Curtiss, J. (2016). Interpersonal Emotion Regulation Questionnaire (IERQ): Scale Development and Psychometric Characteristics. Cognitive Therapy and Research, 40(3), 341-356. https://doi.org/10.1007/s10608016-9756- 2

Hyun, Ji., \& Yi, M. (2013). The influence of cognitive coping on hope, depression and satisfaction with life in hemodialysis patients. Korean Journal of Adult Nursing, 25(4), 389-399. https://doi.org/10.7475/kjan.2013.2 $\underline{5.4 .38} \underline{9}$

Ian, Sherrer. (2007). Hemodialysis and the approach of biopsychology. University of California San Fransisco. Vol. 37(5), 509-520. 
INFODATIN Ginjal Indonesia. 2016. Riset Kesehatan Ginjal Indonesia: Kementrian Kesehatan RI

Isroin. (2017). Kemampuan Adaptasi, Peran, dan Konsep Diri pada Pasien Hemodialisa. Fakultas Kedokteran, Kesehatan Masyarakat, dan Keperawatan UGM, Vol.52 No.1

Kallay, E., Pop, R., \& Balazsi, R. (2009). Emotional profile and quality of life in chronic renal failure and renal transplant patients. Cognition, Brain, Behavior: An Interdisciplinary Journal, 13(3), 313-328. Retrieved from

http://ovidsp.ovid.com/ovidweb.cgi $? \mathrm{~T}=\mathrm{JS}$

$\underline{\& P A G E}=$ reference $\& \mathrm{D}=$ psyc $6 \& \mathrm{NE}$ $\underline{\mathrm{WS}=\mathrm{N}} \underline{\& A N=2009-21493-006}$

Kaplan, Atara. (1983). Psychological Problems in Kidney Failure and Their Treatment. New York: Springer Science Plenum Publishing Corporation

Kubler, Ross. E. (2014). On Death and Dying. What the Dying Have to Teach Doctors, Nurses, Clergy and Their Own Families. Elisabeth Kübler-Ross . The Quarterly Review of Biology. https://doi.org/10.1086/406574

Law J., Garrett Z., \& Nye C. (2010). Emotion and The Approach. The Chocrane Library.5-10.

Lazarus, S. Richard. (1994). Coping with aging. Nursing Times, 93(37), 21. https://doi.org/10.1016/j.jomh.200 $\underline{8.06 .02} \underline{6}$

Mccracken, L. M., Vowles, K. E., \& Eccleston, C. (2004). Chronic Pain Acceptance Questionnaire - Revised (CPAQ-R). Pain, 107(October 2006), 159-166. Retrieved from https://www.div12.org/wp content/uploads/2015/06/ChronicPainAcceptance-Questionniare-
Revised O'Connor, S. M., Jardine, A. G., \& Millar, K. (2008). The prediction of self-care behaviors in end-stage renal disease patients using Leventhal's SelfRegulatory Model. Journal of Psychosomatic Research, 65(2), 191-200.

https://doi.org/10.1016/i.jpsychore s.2008. 02.008

Oltmanns, Thomas. 2013. Psikologi Abnormal Edisi Ketujub Buku 1. Jakarta: Pustaka Pelajar.

Pop-Jordanova, N. D., \& Polenakovic, M. H. (2013). Psychological characteristics of patients treated by chronic maintenance hemodialysis. International Journal of Artificial Organs, 36(2), $\quad$ 77-86. https://doi.org/10.5301/ijao.500018 $\underline{8}$

Price, S. A. \& Wilson, L. M. 1995. Patofisiologi: Konsep Klinis ProsesProses Penyakit, Edisi 4, EGC, Jakarta.

Riset Kesehatan Dasar. 2016. RisetRiset Kesehatan Masyarakat dan Prevalensi Kesehatan Indonesia:

Kementrian Kesehatan RI

Salem, M. (1995). Hypertension in the Hemodialysis Population: A Survey of 649 Patients. 461-468.

Setiawati, Farida Agus. 2016. Statistika Terapan untuk Penelitian Pendidikan dan Sosial. Yogyakarta: Parama Publishing

Shalhub, S., Chang, R. W., Panetta, T., Schutzer, R., Kissin, M., Hacker, R., \& Chawla, A. (2014). Hemodialysis access. Endovascular Interventions: A Case-Based Approach. https://doi.org/10.1007/978-14614-7312-1_77

Straub. (2014). Psychology in Pyhsical Approach. Stanford, USA:Cengage Learning 
Sumintono, B., \& Widiharso, W. (2013). Aplikasi Model Rasch Untuk Penelitian Imu-Ilmu Sosial. Cimahi: Trim Komunikata Publishing

Sundberg. N. D., 2007. Psikologi Klinis Perkembangan Teori, Praktik, dan Penelitian. Edisi keempat. Yogyakarta: Pustaka Pelajar.

Suwitra, K. 2006. Penyakit Ginjal Kronik, dalam: Buku Ajar Penyakit Dalam. Jakarta: Pusat Penerbitan Ilmu Penyakit Dalam FKUI

Telford, K., Kralik, D., \& Koch, T. (2006). Acceptance and denial: Implications for people adapting to chronic illness: literature review. Journal of Advanced Nursing, 55(4), 457-464. https://doi.org/10.1111/j.1365 2648.2006.03942.x

Widakdo, G., \& Besral. (2013). Efek Penyakit Kronis terhadap Gangguan Mental Emosional [Effects of Chronic Disease on Emotional Mental Disorders]. Jurnal Kesehatan Masyarakat Nasional, 7(7), 309-316. https://doi.org/http://dx.doi.org/1 $0.21109 /$ kes mas.v7i7.29

Zalewska, A., Miniszewska, J., Chodkiewicz, J., \& Narbutt, J. (2010). Acceptance of chronic illness in psoriasis vulgaris patients. Journal of the European Academy of Dermatology and Venereology, 21(2), 235-242. https://doi.org/10.1111/j.1468 $\underline{3083.2006 .01912 . x}$ 